\section{Systemic Effects (Risks) of Water Fluoridation}

\author{
Jaime A Cury ${ }^{1}$ (D), Antonio P Ricomini-Filho ${ }^{1}$ (D), Francine L. Perecin
}

Berti $^{2}$, Cinthia PM Tabchoury ${ }^{1}$ D
ISSN 0103-6440

'Piracicaba Dental School, UNICAMP

Universidade Estadual de

Campinas, Piracicaba, SP, Brazil

${ }^{2}$ Pediatric Dentist, Três

Lagoas, MS, Brazil

Correspondence: Prof. Jaime Aparecido Cury, Avenida Limeira, 901, 13414-903 Piracicaba, SP, Brasil. Tel: +55-192106-5303. e-mail: jcury@unicamp.br
Since the 1950s, the benefits and risks of fluoridated water use have been debated worldwide. In the past, it was considered that the systemically ingested fluoride would exert its primary preventive effect after being incorporated into the enamel as fluorapatite, making the enamel more resistant to the caries process; however, it is now recognized that the main effect of water fluoridation is local and post eruptive. On the other hand, irrespective of the caries decline reported worldwide, the anticaries benefit of water fluoridation continues to be observed even in developed countries. Regarding the risks, water fluoridation is considered an acceptable community-based method for fluoride delivery, because the risk of developing dental fluorosis lesions due to the ingestion of fluoride during the enamel formation period has been deemed acceptable when contrasted to the anticaries benefits of fluoride. However, the use of fluoride in water to control caries has created a controversy due to data associating water fluoridation as the cause of some systemic diseases. Therefore, the aim of this descriptive review was to discuss the systemic effects (risks) of water fluoridation use.
Key Words: fluoride, water fluoridation, fluorosis, fluoride toxicity.

\section{Introduction}

In the past, the use of fluoride to control dental caries was classified as systemic or topical, because the lower prevalence of dental caries found in children, who were exposed to fluoridated water during teeth formation, was attributed to fluoride incorporated into enamel during its pre-eruptive mineralization (systemic effect). The concept was that fluoride systemically incorporated into the enamel would make it more resistant (strong) to the acids produced by dental plaque bacteria when dietary sugars are ingested (1).

Considering the current knowledge about the mechanism of action of fluoride on caries control, water fluoridation should be classified as a community-based way of fluoride use and no longer systemic (1). Given the importance of water fluoridation in terms of public health, if it continues to be considered a systemic method, it is implied that we would have to ingest fluoride to be able to control caries. Therefore, the historical mistake of considering fluoride as an essential micronutrient (2) that needs to be ingested, if its concentration in water is not optimal, will be perpetuated. Thus, prenatal and postnatal fluoridated supplements have been suggested based on the recommended daily intake (RDI) of fluoride rather than its anti-caries effect (3). Similarly, supported by RDI, fluoride has been added to dietary products, such as chewing gum.

\section{Mechanism of Action of Fluoride in Water for Caries Control}

Nowadays it is a consensus that the effect of fluoride on caries control is local (topical) and depends on the constant maintenance of fluoride in the oral cavity to interfere with the process of caries lesion development (1). Therefore, water fluoridation is considered the simplest strategy to maintain fluoride constantly present in the oral environment, not only by drinking water daily (Fig. 1), but also by eating food cooked with fluoridated water (4).

Therefore, Figure 2 shows fluoride concentration in saliva of volunteers who ingested a meal containing rice, beans, meat and vegetables cooked with non-fluoridated (control) or fluoridated water ( $0.70 \mathrm{ppm} F$ ) during the time of $15 \mathrm{~min}$ that the foods were masticated and after the ingestion (5). The results clearly show that fluoride absorbed by food during cooking with fluoridated water is released into the mouth during chewing and its concentration remains high for a period thereafter. As can be seen, the effect of fluoridated water extends far beyond that of the water that is drunk.

On the other hand, to maintain fluoride constantly present in the oral environment, by drinking or eating foods prepared with fluoridated water, it is necessary that there is no interruption in fluoride aggregation to water treatment, because our body has no homeostatic mechanism to keep the fluoride concentration constant at any part of it, not even in the mouth. That was shown in Brazil in 1986 when, due to economic problems at that time, fluoridation of water supply in Piracicaba, at São Paulo State, was interrupted for 6 months. As biofilm from children, aged 6-8 years, had been collected a few months before the interruption, new biofilm collections 
were made 2 months after interruption and 2 months after re-fluoridation of the water. Table 1 clearly shows the reduction of fluoride concentration in the biofilm when exposed to non-fluoridated water and the recovery after water was fluoridated again (2). The data were relevant because they were shown in the $80^{\prime}$ of the last century when whether the anticaries effect of fluoride would be systemic or local ("topical") was in discussion and these

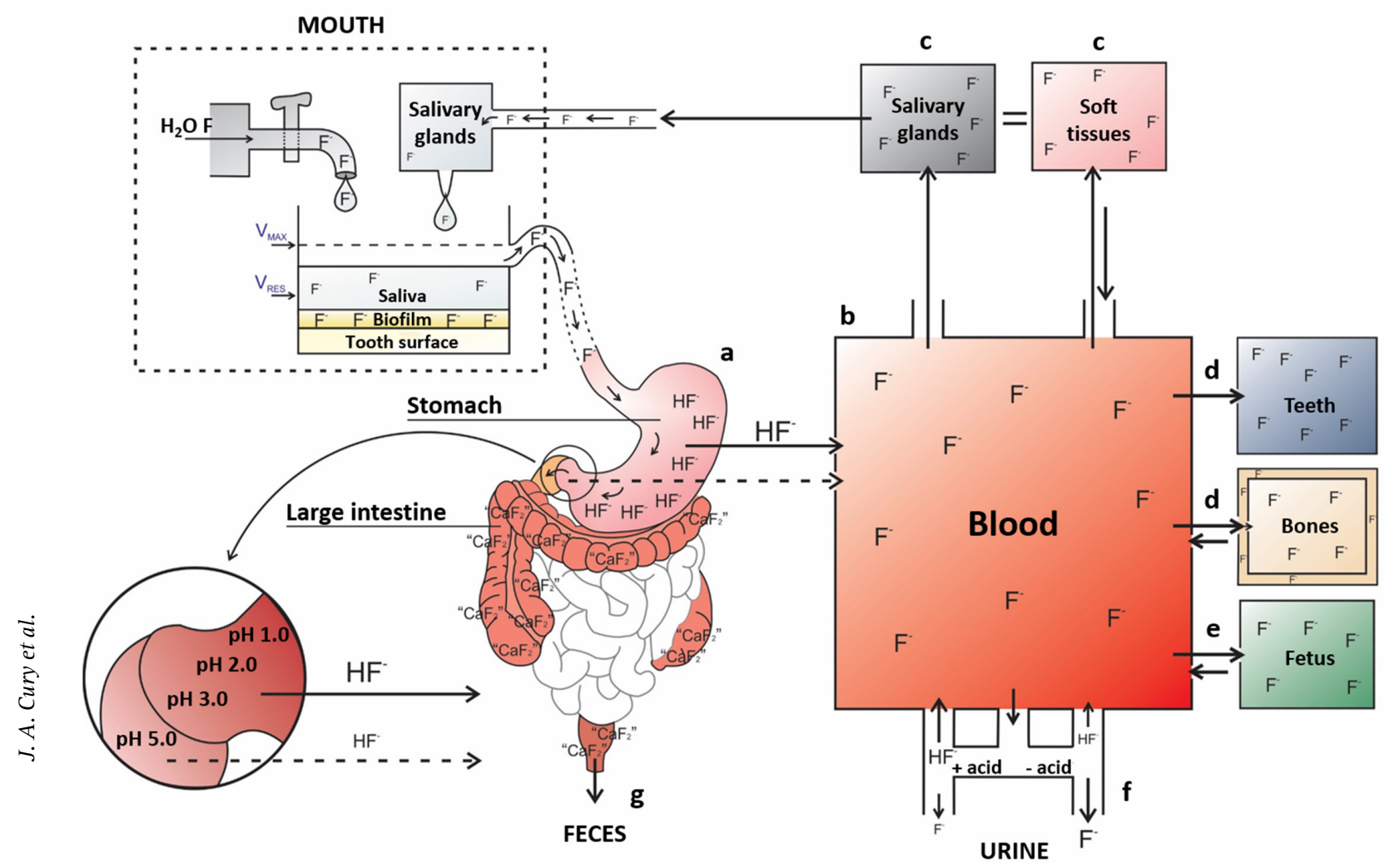

Figure 1. Illustration of fluoride metabolism from drinking water. Ingested fluoride is absorbed mainly in the stomach (as HF form) and also in a lower extent in the intestine (a). The blood (b) is the central compartment from which fluoride (F-) will be distributed throughout the body, returning to the oral cavity via salivary glands (c), or being incorporated into hard tissues (d). In a pregnant woman, the fetus can be considered a sub-compartment of the maternal organism, and F- is equally distributed to its tissues (e). The F- absorbed and circulating throughout the body is excreted in the urine (f), while unabsorbed $\mathrm{F}$ (chemically insoluble in the form of insoluble salts, such as calcium fluoride - CaF $\mathrm{F}_{2}$ is excreted in feces (g).

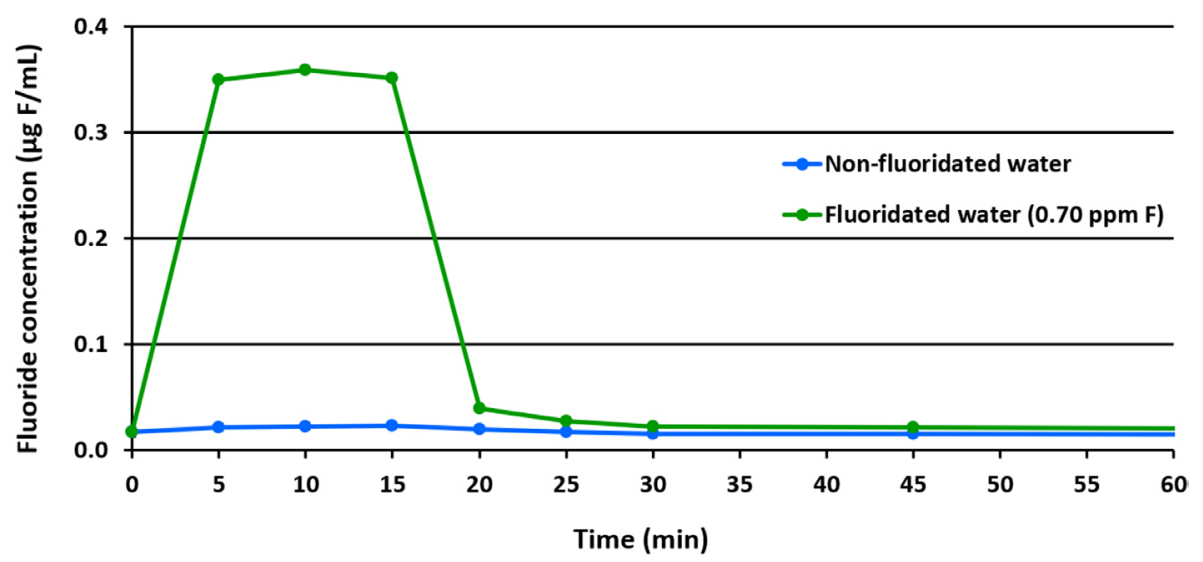

Figure 2. Fluoride concentration in saliva ( $\mu \mathrm{g} \mathrm{F} / \mathrm{mL}$ ) over time due to mastication of food cooked with fluoridated water (0.70 ppm $\mathrm{F}$ - green line) compared with non-fluoridated water (blue line). Fluoride concentration in saliva was determined before meal ingestion (0), during 15 min at meal mastication, and after the mastication period until $60 \mathrm{~min}$. 
results supported the explanation why caries increased when water fluoridation in a city was interrupted or when children who had always lived in a city with fluoridated water moved to another one with non-fluoridated water.

On the other hand, fluoride ingested from water and absorbed in the gastrointestinal tract enters the bloodstream (Fig. 1), and is distributed throughout the body, being able to cause systemic effects, acute or chronic.

\section{Systemic Effects of Fluoride Use}

Over these almost 70 years of water fluoridation history, the fluoride added to the water has been attributed as the cause of several diseases of unknown etiology, as it will be addressed in this article in the subtopic "Other effects of water fluoridation". The systemic side effects of fluoride ingestion are valid for any fluoride source, either natural (e.g. black tea) or the one added to water or dentifrice, and are pharmacologically divided into acute and chronic toxicity. Acute toxicity occurs when great amounts of fluoride are ingested at once, while chronic toxicity occurs when small amounts of fluoride are daily ingested during a person's life (6).

\section{Acute Fluoride Toxicity}

The fluoride ingested in a chemically soluble form is readily absorbed into the gastrointestinal tract (Fig. 1), and

Table 1. Fluoride concentration ( $\mu \mathrm{g} \mathrm{F} / \mathrm{g}=\mathrm{ppm} \mathrm{F}$ ) in dental biofilm of schoolchildren according to conditions of water fluoridation and fluoride concentration in public water supply of Piracicaba, SP, Brazil, 1986-87.

\begin{tabular}{lc}
\hline $\begin{array}{l}\text { Condition of water fluoridation } \\
\text { (fluoride concentration) }\end{array}$ & $\begin{array}{c}\mu \mathrm{g} \mathrm{F} / \mathrm{g} \\
(\text { mean } \pm \text { SD) }\end{array}$ \\
\hline Fluoridated (0.8 ppm F) & $3.2 \pm 1.8(\mathrm{n}=91)$ \\
Interrupted (0.06 ppm F) & $0.2 \pm 0.1(\mathrm{n}=41)$ \\
Re-fluoridated (0.7 ppm F) & $2.6 \pm 1.9(\mathrm{n}=55)$ \\
\hline
\end{tabular}

the first signs and symptoms of the ingestion of excessive amounts of fluoride are nausea and vomiting (7). These symptoms occur shortly after the ingestion because most of the fluoride is absorbed in the stomach with a maximum peak blood concentration occurring within 30-45 min after oral ingestion (8). Depending on the amount of fluoride ingested that is absorbed, it can lead the victim to cardiac arrest and death.

Due to the cases of lethal fluoride-related accidents that occurred in the past, $5.0 \mathrm{mg}$ of fluoride per kilogram of body weight was established as the probably toxic dose (PTD) for acute fluoride exposure (9). Thus, the data shown in Table 2 confirm that water fluoridation is extremely safe considering acute fluoride toxicity, since a 5-6 years old child weighing $20 \mathrm{~kg}$ would have to ingest 143 liters of water at $0.70 \mathrm{ppm} F$ (optimal fluoride concentration for the temperatures in Brazil) to be exposed to the PTD of $5.0 \mathrm{mg} \mathrm{F} / \mathrm{kg}$. On the other hand, lethal accidents have already occurred with the ingestion of fluoridated tablets by children.

\section{Chronic Fluoride Toxicity}

Chronic toxicity refers to the ingestion of small amounts of fluoride for an extended period of time and, since fluoride has affinity only to mineralized tissues, there is a risk to teeth and bones, however there are evident differences between them. Therefore, while for the teeth the critical period is limited to the child's age in which the teeth are under development (pre-eruptive systemic effect), for the bones the risk is perpetuated throughout the person's life. There are also differences in the mechanism of action of fluoride in the development of dental and bone (skeletal) fluorosis because teeth (enamel) and bone are formed by totally different ways.

\section{Dental Fluorosis}

Dental fluorosis is the only systemic side effect of

Table 2. Fluoride concentration in fluoridated products, amount of fluoride in $1 \mathrm{~mL}$ or $1 \mathrm{~g}$ of product and amount of product required to expose a $20 \mathrm{~kg}$ child (5-6 years old) to the probably toxic dose (PTD) of $5.0 \mathrm{mg} \mathrm{F} / \mathrm{kg}$

\begin{tabular}{lccc}
\hline Product & $\begin{array}{c}\text { Fluoride (F) } \\
\text { concentration (ppm F) }\end{array}$ & $\begin{array}{c}\text { Amount of F in } \\
1 \mathrm{~mL} \text { or 1 g }\end{array}$ & $\begin{array}{c}\text { Amount of product required for a 5-6 years } \\
\text { old child (20 kg) to be exposed to the PTD }\end{array}$ \\
\hline Fluoride Varnish (5\% NaF) & 22,000 & $22 \mathrm{mg} / \mathrm{g}$ & $4.5 \mathrm{~g}$ \\
Acidulated phosphate fluoride gel (1.23\% F) & 12,300 & $12.3 \mathrm{mg} / \mathrm{g}$ & $8.1 \mathrm{~g}$ \\
Mouthrinse for weekly use (0.2\% NaF) & 900 & $0.9 \mathrm{mg} / \mathrm{mL}$ & $111 \mathrm{~mL}$ \\
Dentifrice (0.11\% F) & 1,100 & $1.1 \mathrm{mg} / \mathrm{g}$ & $90 \mathrm{~g}(1 \mathrm{tube})$ \\
Mouthrinse for daily use (0.05\% NaF) & 225 & $0.225 \mathrm{mg} / \mathrm{mL}$ & $444 \mathrm{~mL}$ \\
Fluoride supplement (2.21 mg of $\mathrm{NaF})$ & & $1.0 \mathrm{mg} \mathrm{F} /$ tablet & 100 tablets \\
Optimally fluoridated water & 0.7 & $0.0007 \mathrm{mg} / \mathrm{mL}$ & 143 liters
\end{tabular}


fluoridated water ingestion at optimal concentration (0.7 ppm F in Brazil) (10). The knowledge about the mechanism of development of fluorosis is important to understand the risk period of its occurrence and the clinical relevance for the surveillance rules that regulate the reason for this optimal concentration.

\section{Mechanism of Dental Fluorosis Development}

Dental fluorosis affects the tooth under development and once all teeth have been formed, which occurs up to 7 years of age, there will be no longer concern about dental problems related to the chronic systemic effect of water fluoridation.

The effect of fluoride on the development of dental enamel (amelogenesis) is not cellular based, since fluoride affects the extracellular process of enamel mineralization (2). Enamel development occurs in synchronized stages. First, the ameloblast synthesizes and secretes out of the cells specific proteins that form the enamel matrix. The matrix, which has a 25\% protein content, then undergoes the mineralization process. During the mineralization, the protein matrix is resorbed and replaced by calcium and phosphate-based minerals (apatite), leading to the formation of a highly mineralized structure, which contains $95 \%$ minerals, $4 \%$ water and $1 \%$ organic matter.

The resorption (degradation) of enamel matrix proteins, which is made by proteolytic enzymes produced and secreted into the extracellular space by the ameloblasts, is inhibited by fluoride. As the protein degradation is reduced, a less mineralized enamel is formed, with more space between the enamel apatite crystals. The consequence is a more porous enamel that can be clinically seen as opacities of different degrees of alteration, which may compromise the dental aesthetics and quality of life of affected people.

Since fluorosis is a chronic systemic effect of the fluoride circulating in the body, the change induced in enamel should be a function of the daily dose of fluoride that the child is exposed during tooth formation, i.e. the amount ingested according to the child's weight ( $\mathrm{mg} F / \mathrm{kg}$ ). However, as fluorosis is a chronic disease, the duration of fluoride exposure during the amelogenesis is more important (11) than sporadic dose peaks (discussed in the following topic).
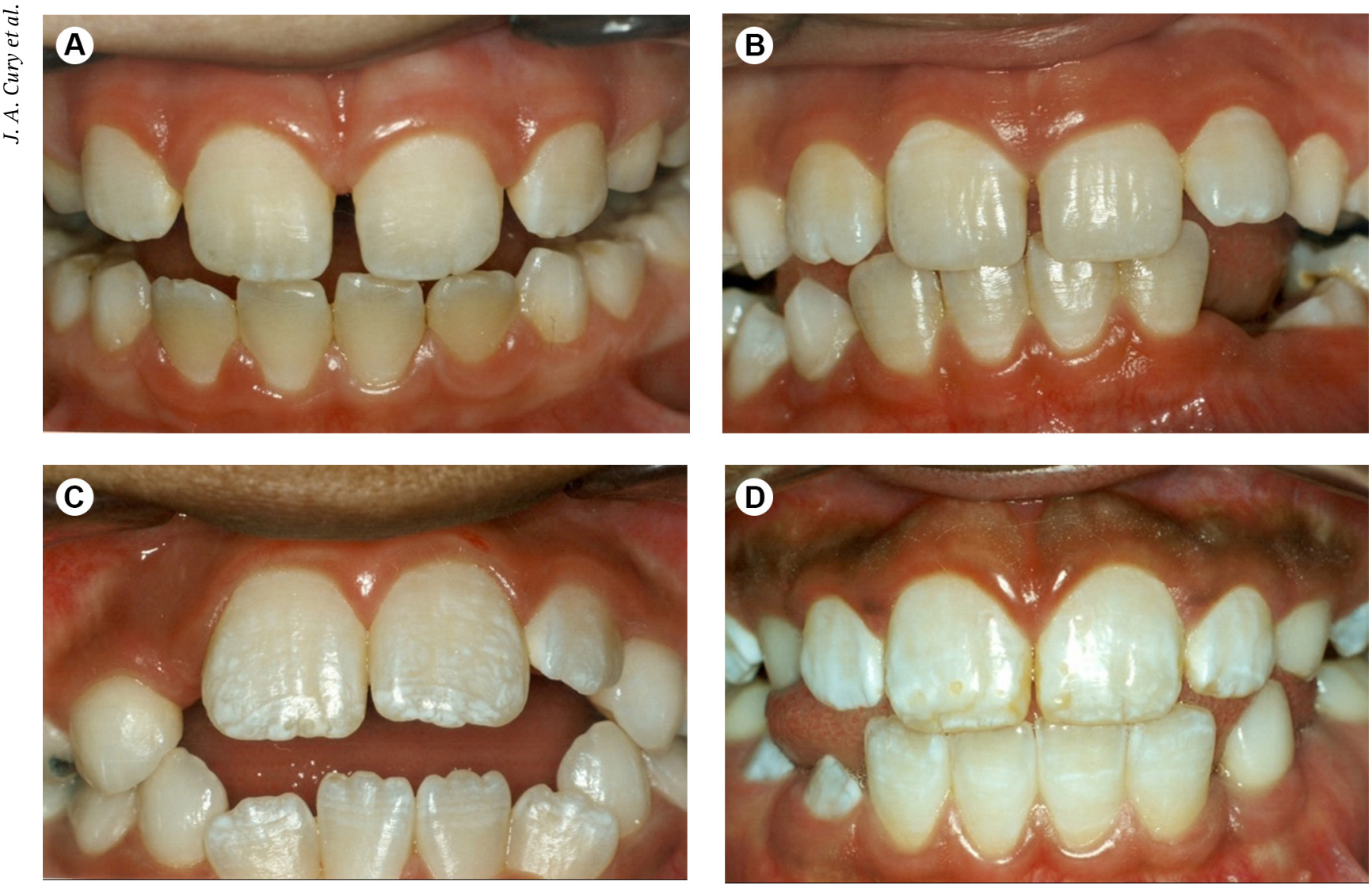

Figure 3. Clinical aspect of the different levels of dental fluorosis. A) very mild (small whitish and opaque spots scattered irregularly on the teeth, involving no more than 25\% of the surfaces); B) mild (the opacity is more extensive, but does not involve more than 50\% of the surfaces); C) moderate (more evident white areas, affecting most of the crown); and D) severe (intense and generalized hypomineralization, with occasional loss of dental structure). Data from children exposed to well water containing 1.4 ppm F, Assistência district, Rio Claro city, SP, Brazil. Pictures kindly donated by Dr Aliete A. Otta-Rui. 
This knowledge is essential to the discussion of the risk of fluorosis when different methods of fluoride are used, as well as the surveillance of the current parameters of values for fluoride concentration in water (12).

Dental fluorosis is a chronic disease that alters the mineral part of the enamel and is classified according to its severity. According to $\mathrm{WHO}$, fluorosis is classified as very mild, mild, moderate and severe, and Figure 3 illustrates these different levels of fluorosis. While very mild and mild fluorosis does not affect a person's quality of life, the same is not true for moderate and severe fluorosis cases (13).

Studies conducted on population of Australia and the United States exposed to optimally fluoridated water show that dental caries affects a person's quality of life more than fluorosis $(14,15)$. Thus, the caries-reducing benefits outweigh the risk of dental fluorosis due to water fluoride ingestion. This is a consequence of the fact that the most prevalent level of fluorosis found in these countries is very mild and the same pattern occurs in Brazil (Fig. 4).

Therefore, water fluoridation at the optimal concentration of $0.7 \mathrm{ppm}$ is safe regarding the severity of the resulting fluorosis. When the fluoride concentration in water is two times higher than the optimal (1.4 ppm F), there is an increased prevalence of moderate and severe fluorosis, as shown in Table 3. This table shows the prevalence of fluorosis in teeth of children exposed to well water containing natural fluoride at a concentration of $1.4 \mathrm{ppm} F$ (School C) compared to children in the same city exposed to non-fluoridated water (Schools A and B).

Thus, $1.5 \mathrm{ppm} F$ is considered the maximum value of natural fluoride concentration allowed in public water supply in Brazil, because the severity of fluorosis reaches levels that could compromise dental aesthetics (Fig. 5), and therefore people's quality of life.

\section{Risk Dose for Dental Fluorosis}

While there is evidence that the dose of $5.0 \mathrm{mg} \mathrm{F} / \mathrm{kg}$ of body weight is a useful parameter for estimating the risk for accidents with fluoride ingestion considering acute fluoride toxicity, the same is not true for the relationship between dose and dental fluorosis. The dose of $0.05-0.07 \mathrm{mg}$ F/day/ $\mathrm{kg}$ body weight has been currently considered as an upper limit of fluoride ingestion considering the balance between the benefit of caries reduction and the resulting risk of fluorosis. Dozens of papers have been published about the dose that children are submitted considering fluoride intake from water and dentifrice, but most are limited on the amount of fluoride ingested and how much it exceeds the limit of $0.05-0.07 \mathrm{mg}$ $\mathrm{F} /$ day $/ \mathrm{kg}$. Moreover, comparisons are made regarding the percentage contribution of each fluoride source to the total ingestion dose, but unfortunately not correlating with the outcome of fluorosis (17). Indeed, only two longitudinal studies

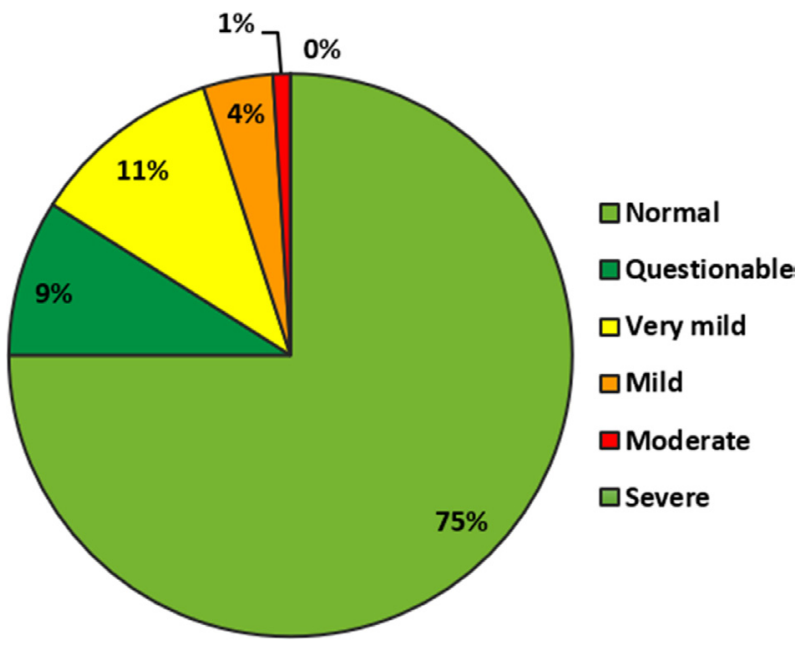

Figure 4. Prevalence of dental fluorosis in Brazil, according to SB 2010 (Brazilian Ministry of Health, 2010 national oral health survey) (16). have evaluated the relationship between dose of fluoride ingestion and resulting fluorosis $(18,19)$.

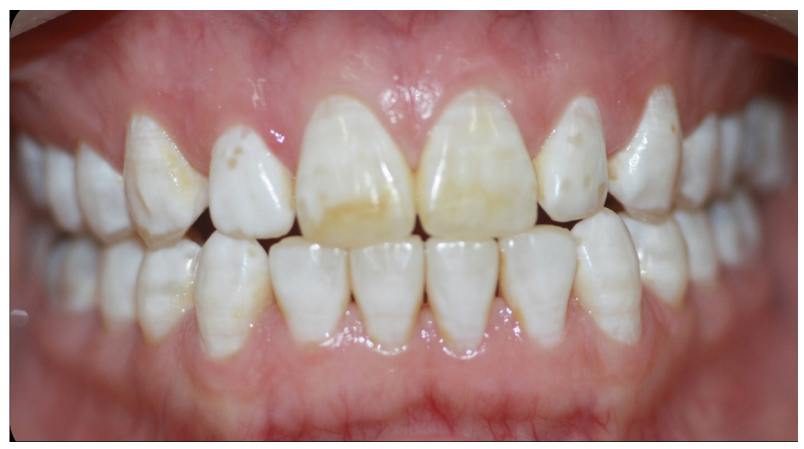

Figure 5. Child presenting severe fluorosis due to exposure to well water containing $1.4 \mathrm{ppm} \mathrm{F}$. 
In Brazil, the relationship between the fluoride dose to which 2-3 years old children were exposed by the ingestion of fluoridated water (liquids and solid foods) and fluoride dentifrice (Table 4) (20), and the resulting fluorosis on permanent incisors of these children when they were 7-8 years old was evaluated (18). At the age that the permanent incisors were under development, the children were exposed to a total dose of $0.09 \mathrm{mg} \mathrm{F} /$ $\mathrm{kg} /$ day, $30 \%$ higher than the upper limit value considered for clinically acceptable fluorosis risk (Table 4). Twentynine children (59\%) had fluorosis, but 20 children (41\%) showed no clinically detectable fluorosis. Of those who had fluorosis, 90\% of them had very mild fluorosis, which does not compromise people's quality life as discussed earlier in this article.

This data is consistent with the SB 2010 fluorosis data from the national oral health survey conducted in Brazil (Fig. 4) (16), which showed that the most prevalent fluorosis score was very mild (11\%). The non-linear relationship between dose and fluorosis can be explained by the fact that not all ingested fluoride is absorbed in gastrointestinal tract and causes a systemic effect (21). Another explanation, particularly related to dentifrice, $\vec{s}$ is the overestimation of the ingestion dose based on the mother's information of the daily frequency that the child brushes the teeth.

The other prospective work on the relationship between the ingestion dose and resulting fluorosis was conducted in USA and was based on the estimate of total fluoride ingestion from water, dentifrice and supplements, as well as other food and juices prepared with or containing water (19). The authors justified the relevance of the study considering that although the 'optimal' fluoride ingestion between 0.05 and 0.07 (mg F/ $\mathrm{kg}$ ) has been accepted for decades, it is based on limited scientific evidence and the authors concluded that: "Given the overlap among caries/fluorosis groups in mean fluoride intake and extreme variability in individual fluoride intakes, firmly recommending an "optimal" fluoride intake is problematic".

Table 4. Dose of fluoride ingestion (mg F/kg/day) by children (20-30 months old) from Piracicaba, SP, Brazil $(n=39)$ and Ibiá, MG, Brazil $(n=32)$ due to the ingestion of fluoridated water (diet of liquids and solids) and fluoride dentifrice.

\begin{tabular}{lccc}
\hline \multirow{2}{*}{ City location } & \multicolumn{3}{c}{$\mathrm{mg} \mathrm{F} / \mathrm{kg}$ body weight/day } \\
\cline { 2 - 4 } & Diet & Dentifrice & Diet + Dentifrice \\
\hline $\begin{array}{l}\text { Piracicaba, SP, } \\
\text { (kindergarten) }\end{array}$ & 0.04 & 0.052 & 0.092 \\
$\begin{array}{l}\text { Ibiá, MG, (home) } \\
0.027\end{array}$ & 0.061 & 0.088 \\
\hline
\end{tabular}

On the other hand, there is a linear relationship between fluoride concentration in water and dental fluorosis (22). However, as already discussed in this article, since fluorosis is a chronic disease, the period of fluoride exposure during teeth development is more important than larger doses for short periods of time. Evidence for that was shown in a study that evaluated the prevalence of dental fluorosis in children from two different cities in São Paulo State (23). Both cities were participating of an external program of quality of fluoride concentration in water, whose analysis showed that while in one of the cities there was regularity of fluoride concentration within the optimum range from 0.6 to $0.8 \mathrm{ppm} \mathrm{F}$, in the other one sporadic values up to $1.4 \mathrm{ppm} \mathrm{F}$ were found. However, the prevalence of fluorosis in children from the city with homogeneous fluoride concentration in water was two times higher than that found in the other city. Although the prevalence was higher, the severity of fluorosis did not affect the children's satisfaction with their teeth. The relevance of the period that the oscillating chronic dose for fluorosis development lasts was further experimentally confirmed (23).

Therefore, the knowledge that fluorosis depends more on the period of exposure to a certain fluoride dose than high dose peaks should cause concern to the current surveillance parameters for fluoride concentration in water. According to the Brazilian Ordinance 635 (24), the fluoride concentration in water supply must be kept adjusted between a minimum of 0.6 and a maximum of $0.8 \mathrm{ppm}$ F. This ordinance does not consider that both caries and fluorosis are chronic diseases and thus the anti-caries benefit will not be lost and the risk of fluorosis will not be increased if the concentration is below 0.6 or above $0.8 \mathrm{ppm} F$, respectively, for a short period of time. Therefore, this knowledge supports a consensus recommendation for the evaluation and interpretation of fluoride concentration in water that considers the benefits and risks of certain fluoride concentration ranges in water, than the current dichotomous ordinance (25).

Table 5. Chronology of campaigns against water fluoridation and allegations used (modified from Newbrun, 1996).

\begin{tabular}{lc}
\hline Year & Allegations \\
\hline 1950 & Communist plan \\
1960 & Toxic waste, polluting \\
1970 & Government conspiracy \\
1980 & Industrial interests, cancer in humans, \\
1990 & Aging, Alzheimer's disease \\
$2000-$ present & AIDS, bone fracture, birth rate \\
\hline
\end{tabular}




\section{Bone Fluorosis (Skeletal)}

The differences between dental and bone fluorosis begin with the fact that the processes by which enamel and bone undergo mineralization (calcification) are totally distinct. Therefore, it is not surprising that the type of change caused by the systemic effect of the fluoride ingested and the effect of the fluoride concentration in the water used are different.

Both tooth enamel and bone formation are mediated by cells, ameloblast and osteoblast, respectively. While ameloblast has only one chance to make a defect-free enamel, because it has a programmed life, osteoblast works its entire life. Both begin the process of enamel and bone formation by synthesizing and secreting a protein matrix that is deposited in the extracellular space. In addition to the protein composition of the matrices being totally different, their mineralization process is also distinct. While enamel mineralization is preceded by the resorption of matrix proteins, the collagen matrix of bone is mineralized without resorption. In enamel, the fluoride circulating in the body and present in the extracellular matrix fluids inhibits the resorption of proteins, forming a hypomineralized mineral tissue, and in bone, the tissue becomes hypermineralized due to different effect mechanisms. Therefore, while the enamel under development is sensitive to low concentrations of fluoride by water exposure (less than $1.0 \mathrm{ppm} F$ ) in a short period, bone changes are only caused by 5 to 10 -fold higher concentrations and prolonged exposure to fluoride.

Accordingly, it is known that fluoride in water at a concentration of approximately $1.0 \mathrm{ppm} F$ does not affect bone strength, bone mineral density and the prevalence of bone fractures (10). These results have recently been confirmed both in the United States, where there is a water fluoridation program, and in Sweden, where fluoride is not added to the water treatment, but is naturally found in the drinking water. Thus, the bone density of children from the United States exposed to fluoride from birth to 15 years old was determined and no significant correlation was found between fluoride ingestion dose and bone densitometry determined by DXA (26). In Sweden, a study was conducted with 473,277 people exposed to water containing natural fluoride at concentrations of 0.3 to $1.5 \mathrm{ppm} \mathrm{F}$ and no association was found between chronic long-term fluoride exposure and pelvic fracture (27). These results from US and Sweden cohort studies prove the safety of water fluoridation at optimal concentration in terms of risk of skeletal fluorosis.

\section{Other Effects Alleged To Water Fluoridation}

Since 1950, when the aggregation of fluoride to public water was implemented in the United States, it has suffered harsh contestations, and the reasons for that have changed from decades to decades and from one century to another (Table 5). It was already alleged to be a communist plan developed by the Russians after World War II to reduce American intelligence, and thus, the former Soviet Union could rule the world. This political allegation of the last century, in the form of "conspiracy theory," has now been fomented by the allegation that fluoride is a neurotoxin that affects the IQ of people exposed to fluoridated water.

These and other allegations, such as fluoride causing hypothyroidism, are based in transversal studies of associations and not cause-effect, which have been scientifically contested with elegance (28-31). Thus, the adjustment of fluoride concentration during water treatment is still recommended by WHO, because the only systemic side effect associated with optimally fluoridated water ingestion is dental fluorosis, which does not compromise the quality of life of affected people.

\section{Conclusions}

1. Fluoride absorbed by the body and circulating in the blood has the potential to manifest side effects, either acute or chronic.

2. Acute effect of fluoride exposure can cause problems from gastro-intestinal to death.

3. Fluoride, from any method of chronic and daily use, ingested and absorbed during the teeth development is a risk factor for dental fluorosis (chronic systemic effect).

4. Excluding dental fluorosis, there is no evidence that fluoride in water at optimal concentration causes any other systemic effects on humans.

5. Dental fluorosis resulting from the exposure to fluoridated water at optimal concentration is very mild to mild level, which does not compromise the quality of life of people affected.

\section{Resumo}

Desde 1950, os benefícios e riscos do uso da água fluoretada têm sido debatidos mundialmente. No passado, foi considerado que o fluoreto ingerido sistemicamente exerceria seu efeito preventivo de cárie pela sua incorporação ao esmalte como fluorapatita, tornando o esmalte mais resistente ao processo de desenvolvimento de lesões de cárie; entretanto, é atualmente reconhecido que o principal efeito da fluoretação da água é local e pós-eruptivo. Por outro lado, independente do declínio de cárie que tem sido observado mundialmente, o benefício anticárie da fluoretação da água continua sendo observado mesmo em países desenvolvidos. Com relação aos riscos, fluoretação da água é considerada uma estratégia aceitável de saúde pública para uso de fluoreto, porque o risco de desenvolvimento de fluorose dental devido à ingestão de fluoreto durante o período de formação do esmalte foi considerado aceitável quando comparado aos benefícios anticárie do flúor. Entretanto, o uso de fluoreto na água para controlar cárie tem gerado controvérsias devido a dados de pesquisa que associam fluoretação da água como causa de algumas doenças sistêmicas. Assim, o objetivo dessa revisão descritiva foi discutir os efeitos sistêmicos (riscos) da fluoretação da água.. 


\section{Acknowledgements}

Based on the conference done by the 1st author at the 5th State Seminar Water and Health, CVS-SP/FSP-USP, São Paulo, Brazil, 12/10/2015.

\section{References}

1. Tenuta LM, Cury JA. Fluoride: its role in dentistry. Braz Oral Res 2010;24:9-17.

2. Fejerskov 0 , Cury JA, Tenuta LMA, Marinho V: Fluorides in caries control; in Fejerskov 0, Nyvad B, Kidd E (eds): Dental Caries: The Disease and Its Clinical Management, ed 3. Oxford, Wiley-Blackwell, 2015, pp245-276.

3. Rebelo MAB, Fernandez-Alves CS, Bulcão LN, Cury JA. Benefits and risks of fluoride supplements of Brazilian Market (In Portuguese). Vig Sanit Debate 2014;2:80-85.

4. Cury JA, Tenuta LM. How to maintain a cariostatic fluoride concentration in the oral environment. Adv Dent Res 2008;20:13-16.

5. Lima CV, Tenuta LMA, Cury JA. Fluoride increase in saliva and dental biofilm due to a meal prepared with fluoridated water or salt: a crossover clinical study. Caries Res 2019;53:41-48.

6. Nobrega FF, Tenuta LMA, Cury JA. Metabolism and toxicity of fluoride. In: Oral Biochemistry (In Portuguese). Cury JA, Tenuta LMA, Tabchoury CPM (Editors) 1st ed. São Paulo: Artes Médicas 2017. p.124-144.

7. Cury JA, Tenuta LMA. Acute intoxication by fluoride ingestion. In: Medical emergencies in Dentistry (In Portuguese). Andrade EA, Ranali J (Editors) 3rd ed. São Paulo: Artes Médicas 2011. p.145-152.

8. Ekstrand J. Fluoride metabolism. In: Fluoride in dentistry. Fejerskov 0 , Ekstrand J, Burt B (Editors) 2nd ed. Copenhagen: Munksgaard 1996 p.55-68.

9. Whitford GM. Acute and chronic fluoride toxicity. J Dent Res 1992;71:1249-1254.

10. Frazão $P$, Peres MA, Cury JA. Drinking water quality and fluoride concentration. Rev Saude Publica 2011;45:964-973.

11. Bärdsen A. "Risk periods" associated with the development of dental fluorosis in maxillary permanent central incisors: a meta-analysis. Acta Odontol Scand 1999;57:247-256.

12. Bergamo ET, Barbana M, Terada RS, Cury JA, Fujimaki M. Fluoride concentrations in the water of Maringá, Brazil, considering the benefit/ risk balance of caries and fluorosis. Braz Oral Res 2015;29:1-6.

13. Chankanka O, Levy SM, Warren JJ, Chalmers JM. A literature review of aesthetic perceptions of dental fluorosis and relationships with psychosocial aspects/oral health-related quality of life. Community Dent Oral Epidemiol 2010;38:97-109.

14. Onoriobe U, Rozier RG, Cantrell J, King RS. Effects of enamel fluorosis and dental caries on quality of life. J Dent Res. 2014;93:972-979.

15. Do LG, Ha DH, Spencer AJ. Natural history and long-term impact of dental fluorosis: a prospective cohort study. Med J Aust. 2016;18;204:225.

16. Brazil. Ministry of Health. SB Brazil 2010: National Oral Health Survey: main results. Ministry of Health. Health Care Secretariat. Health Surveillance Secretariat. Brasilia: Ministry of Health, 2012. (In Portuguese).
17. Oliveira MJ, Martins CC, Paiva SM, Tenuta LM, Cury JA. Estimated fluoride doses from toothpastes should be based on total soluble fluoride. Int J Environ Res Public Health 2013;10:5726-5736.

18. Martins CC, Paiva SM, Lima-Arsati YB, Ramos-Jorge ML, Cury JA. Prospective study of the association between fluoride intake and dental fluorosis in permanent teeth. Caries Res 2008;42:125-133.

19. Warren JJ, Levy SM, Broffitt B, Cavanaugh JE, Kanellis MJ, WeberGasparoni K. Considerations on optimal fluoride intake using dental fluorosis and dental caries outcomes--a longitudinal study. J Public Health Dent 2009;69:111-115.

20. Paiva SM, Lima YB, Cury JA. Fluoride intake by Brazilian children from two communities with fluoridated water. Community Dent Oral Epidemiol 2003;31:184-191.

21. Falcão $A$, Tenuta $L M$, Cury JA. Fluoride gastrintestinal absorption from $\mathrm{Na}_{2} \mathrm{FPO}_{3} / \mathrm{CaCO}_{3}$ - and $\mathrm{NaF} / \mathrm{SiO}_{2}$-based toothpastes. Caries Res 2013:47:226-233.

22. Fejerskov 0 , Baelum $V$, Richards A. Dose-response and dental fluorosis. In: Fluoride in dentistry. Fejerskov 0, Ekstrand J, Burt B (Editors) 2nd ed. Copenhagen: Munksgaard, 1996; p.153-166.

23. Catani DB, Hugo FN, Cypriano S, Sousa Mda L, Cury JA. Relationship between fluoride levels in the public water supply and dental fluorosis. Rev Saude Publica 2007:41:732-739.

24. Brazil. Ordinance 635 of December 26, 1975. Approves norms and standards on the fluoridation of water from public supply systems. Available in [2006 jan 18]: http://www.saude.gov/programas/bucal/ principal.htm (In Portuguese).

25. [CECOL / USP]. Collaborating Center of the Ministry of Health in Oral Health Surveillance. Technical consensus on public water supply classification according to fluoride content. São Paulo: School of Public Health, University of São Paulo; 2011. (In Portuguese).

26. Levy SM, Warren JJ, Phipps K, Letuchy E, Broffitt B, EichenbergerGilmore J, et al. Effects of life-long fluoride intake on bone measures of adolescents: a prospective cohort study. J Dent Res 2014;93:353-359.

27. Näsman $P$, Ekstrand J, Granath F, Ekbom A, Fored CM. Estimated drinking water fluoride exposure and risk of hip fracture: a cohort study. J Dent Res 2013;92:1029-1034.

28. Newton JN, Young N, Verne J, Morris J. Water fluoridation and hypothyroidism: results of this study need much more cautious interpretation. J Epidemiol Community Health 2015;69:617-618.

29. Grimes DR. Commentary on "Are fluoride levels in drinking water associated with hypothyroidism prevalence in England? A large observational study of GP practice data and fluoride levels in drinking water". J Epidemiol Community Health 2015;69:616.

30. Warren JJ, Saraiva MC. No Evidence Supports the Claim That Water Fluoridation Causes Hypothyroidism. J Evid Based Dent Pract 2015;15:137-139.

31. Newton JN, Verne J, Dancox M, Young N. Are fluoride levels in drinking water associated with hypothyroidism prevalence in England? Comments on the authors' response to earlier criticism. J Epidemiol Community Health 2017;71:315-316.
Received June 12, 2019 Accepted August 26, 2019 